\title{
Effect of temperature on the life history of Encarsia bimaculata (Hymenoptera: Aphelinidae), a parasitoid of Bemisia tabaci (Hemiptera: Aleyrodidae)
}

\author{
BaO-Li QIU ${ }^{1}$, Paul J. DE BARRO ${ }^{2}, \mathrm{CAI}_{-} \mathrm{XIA} \mathrm{XU}^{1}$ and Shun-XIANG REN ${ }^{1 *}$ \\ ${ }^{1}$ Department of Entomology, South China Agricultural University, Wushan Road, Guangzhou, 510640, P.R. China; \\ e-mail: baileyqiu@yahoo.com.cn; baileyqiu@scau.edu.cn \\ ${ }^{2}$ CSIRO Entomology, 120 Meiers Road, Indooroopilly, Queensland 4068, Australia
}

Key words. Encarsia bimaculata, Bemisia tabaci, B biotype, life history, temperature, biology, biological control

\begin{abstract}
Encarsia bimaculata (Heraty \& Polaszek) is an abundant parasitoid of Bemisia tabaci in southern China. The effects of constant temperatures on a range of life history traits, including development, survival of immatures, longevity and reproduction of adults, were studied in the laboratory. The developmental period from egg to adult ranged from $34.3 \pm 0.4 \mathrm{~d}$ at $20^{\circ} \mathrm{C}$ to $8.7 \pm 0.6 \mathrm{~d}$ at $32^{\circ} \mathrm{C}$, A total of $181.4 \pm 2.4$ degree-days were required to complete development with a lower developmental threshold of $11.6 \pm$ $0.3^{\circ} \mathrm{C}$. The survivorship of E. bimaculata from $2^{\text {nd }}$ instar to adult varied from $81.3 \pm 1.7 \%$ at $20^{\circ} \mathrm{C}$ to $91.0 \pm 1.8 \%$ at $26^{\circ} \mathrm{C}$. Average adult female longevity was $8.4 \pm 0.7 \mathrm{~d}$ at $20^{\circ} \mathrm{C}$ and $5.4 \pm 0.4 \mathrm{~d}$ at $32^{\circ} \mathrm{C}$, and daily production of offspring peaked at $29^{\circ} \mathrm{C}$ with 4.5 offspring per female. The maximum oviposition occurred three days after adult emergence at $23,26,29$ and $32^{\circ} \mathrm{C}$, and four days at $20^{\circ} \mathrm{C}$. Total number of offspring produced per female varied from $24.3 \pm 2.0$ at $32^{\circ} \mathrm{C}$ to $29.3 \pm 2.9$ at $20^{\circ} \mathrm{C}$. The maximum intrinsic rate of increase $\left(r_{m}\right)$ was $0.2163 \pm 0.013$ at $29^{\circ} \mathrm{C}$, followed by $0.2062 \pm 0.022$ at $32^{\circ} \mathrm{C}$. Results indicate that E. bimaculata reaches its maximum biological potential at temperatures ranging from $26^{\circ} \mathrm{C}$ to $32^{\circ} \mathrm{C}$ with $29^{\circ} \mathrm{C}$ being the optimal temperature.
\end{abstract}

\section{INTRODUCTION}

Sweetpotato whitefly, Bemisia tabaci (Gennadius) (Hemiptera: Aleyrodidae) is an important pest of agriculture and horticulture in many parts of the world (Costa et al., 1993; Brown et al., 1995; Wang \& Tsai, 1996). The first record of B. tabaci in China was in 1949 (Chou, 1949), but it was not considered to be a major pest until the mid 1990s (Ren et al., 2001; Luo et al., 2002; Qiu et al., 2003a). Prior to the mid 1990s, B. tabaci in China most likely belonged to indigenous Asian genetic groups (De Barro et al., 2005). The outbreak and increased status of this pest is attributed to the invasion of $B$. tabaci belonging to the Mediterranean/Asia Minor/Africa race, namely B. tabaci biotype B (Luo et al., 2002; Qiu et al., 2003a; Wu et al., 2003; De Barro et al., 2005). Thereafter, the $\mathrm{B}$ biotype is recorded damaging crops and ornamental plants in more than 25 of China's 34 provinces.

Chemical control is still the key method used in the management of $B$. tabaci, however, this pest can rapidly develop resistance to insecticides and so the sole reliance on insecticides, is unsustainable in the long term (Byrne et al., 2003). Natural enemies, including parasitoids and predators, are regarded as potential agents for use in the classical biological control of this pest (Liu \& Stansly, 1996; McAuslane \& Nguyen, 1996; Gerling et al., 2001; Ren et al., 2001; Qiu et al., 2005). In China, 19 species of aphelinids are recorded parasitizing $B$. tabaci and of these, Encarsia bimaculata (Heraty \& Polaszek) appears to be the principle species in southern China, accounting for $32.3 \%$ and $33.9 \%$ of the parasitism recorded in surveys in southern China between 2000 and 2001 (Qiu et al., 2004a). However, little is known about this parasitoid and its potential as an effective control agent. Qiu \& Ren (2005) investigated the effect of host plants on the development, survival and reproduction of E. bimaculata. Here the effect of temperature on development, survival and reproduction of E. bimaculata is determined in order to assess the potential of this parasitoid for use in classical and augmentative biological control programmes against the B biotype of B. tabaci.

\section{MATERIAL AND METHODS}

\section{Host plant}

Eggplants, Solanum melongena L. var Yuefengzihong are grown individually in $12 \mathrm{~cm}$ diameter plastic pots and used in the experiments at the 4-6 leaf stage.

\section{Insect cultures}

Bemisia tabaci was originally collected on hibiscus, Hibiscus rosa-sinensis L. (Malvaceae) in Teem Plaza, Guangzhou City in 2001, and was identified as B biotype using both RAPD-PCR (De Barro \& Driver, 1997) and mitochondrial CO1 (Frohlich et al., 1999). Encarsia bimaculata was collected near South China Agricultural University and identified by Jian Huang (Fujian Agriculture \& Forestry University, China). Voucher specimens are available from the Laboratory of Biological Control, South China Agricultural University.

Both the whitefly and the parasitoid were maintained on hibiscus in a greenhouse, and a subcolony maintained in rearing cages $(60 \times 60 \times 60 \mathrm{~cm})$ in the laboratory for 10 generations before being used in the experiments. Conditions in the laboratory were $26.0 \pm 0.5^{\circ} \mathrm{C}, 70-80 \%$ relative humidity, $14 \mathrm{~L}: 10 \mathrm{D}$ photoperiod and a light intensity of 3000 Lux.

\footnotetext{
* Corresponding author; e-mail: entomscau@yahoo.com.cn
} 


\section{Developmental period and survival of immatures}

Approximately 40 pairs of $B$. tabaci adults were released into a leaf-clip cage ( $3 \mathrm{~cm}$ diameter and $1.5 \mathrm{~cm}$ high) on the undersurface of either the $3^{\text {rd }}$ or $4^{\text {th }}$ leaf of an eggplant. Adults were allowed to lay eggs for $12 \mathrm{~h}$ before being removed. Preliminary studies showed that E. bimaculata is able to parasitize all the nymphal stages of $B$. tabaci, but prefers the $3^{\text {rd }}$ and $4^{\text {th }}$ instars (Qiu B.-L., unpubl. data), therefore, the $3^{\text {rd }}$ and early $4^{\text {th }}$ instars were used in experiments.

A newly emerged female and two males of E. bimaculata were confined in a petri dish for 4-6 h, and mating was observed at a magnification of $40 \times$ using a binocular microscope. Each mated female was then transferred to a leaf-clip cage containing $3^{\text {rd }}$ or early $4^{\text {th }}$ instar $B$. tabaci B biotype nymphs at an average density of 5.38 nymphs $/ \mathrm{cm}^{2}$ (range 4-11) Females were then left to oviposit for $12 \mathrm{~h}$. From the $4^{\text {th }}$ day post-parasitization, larvae of E. bimaculata within the whitefly nymphs were examined daily using a stereomicroscope to observe the parasitoid larvae through the cuticle of the nymph. The number of parasitoid larvae visible inside a nymph (usually in the early second instar) and the time from oviposition to the emergence was measured. The survival of juvenile parasitoids is also noted.

The experiments were carried out at $17^{\circ} \mathrm{C}, 20^{\circ} \mathrm{C}, 23^{\circ} \mathrm{C}, 26^{\circ} \mathrm{C}$, $29^{\circ} \mathrm{C}, 32^{\circ} \mathrm{C}$ and $35^{\circ} \mathrm{C}$ in separate temperature-humidity controlled incubators (PXY-300Q-A, Shaoguan Keli Experimental Instrument Co., Ltd., Shaoguan, China) at a $70-80 \%$ R.H., $14 \mathrm{~L}$ : $10 \mathrm{D}$ day length and 3000 Lux. The ranges of temperatures are those prevailing in South China. Four batches of thirty $E$. bimaculata larvae were examined at each temperature. Those that died during development were not included in the analysis.

\section{Longevity and reproduction of adult females}

Mated females were obtained as described above, and introduced into leaf-clip cages as above. Parasitoids were transferred to new clip cages every $24 \mathrm{~h}$ and the old leaves were examined daily until the parasitoid larvae were visible in the whitefly nymphs. The longevity and fecundity of each female adult was recorded.

The experiments were carried out at $20^{\circ} \mathrm{C}, 23^{\circ} \mathrm{C}, 26^{\circ} \mathrm{C}, 29^{\circ} \mathrm{C}$ and $32^{\circ} \mathrm{C}$ in separate temperature-humidity controlled incubators at a $70-80 \%$ R.H., $14 \mathrm{~L}: 10 \mathrm{D}$ and $3000 \mathrm{Lux}$. Four batches of thirty female parasitoids were kept at each temperature.

\section{Data analysis}

Differences in developmental times, survival of juveniles, adult longevity and fecundity were compared using analysis of variance (PROC ANOVA, SAS Institute, 2003). Where the differences were significant, means were separated using StudentNewman-Kuel multiple range test at a significant level of $\alpha=$ 0.05 (SAS Institute, 2003).

The life table parameters; intrinsic rate of increase $\left(r_{\mathrm{m}}\right)$, net reproductive rate $\left(R_{\mathrm{o}}\right)$, mean generation time $(T)$, doubling time $(D T)$ and finite rate of increase $(\lambda)$ were computed according to Birch (1948) using a statistical jackknife technique (Maia et al., 2000). The life table parameters were compared using analysis of variance (PROC ANOVA, SAS Institute, 2003). Means were separated using Student-Newman-Kuel multiple range test at a significant level of $\alpha=0.05$ (SAS Institute, 2003). The lower developmental threshold temperature $\left(T_{b}\right)$ was estimated by using a weighted linear regression of mean developmental rate against temperature: $v=a+b \times T$, where $v$ is developmental rate, $a$ and $b$ are constants and $T_{b}=-(a / b)$. Degree-Days $(D D)$ needed for development was calculated as: $D D=\left(T-T_{b}\right) \times D$, where $T$ is treatment temperature $\left({ }^{\circ} \mathrm{C}\right), T_{b}$ is lower developmental threshold temperature, and $D$ is the mean developmental time in days at temperature $T$.

\section{RESULTS}

\section{Developmental periods and survival of immatures}

In all cases, temperature had a significant effect on both development and survival of E. bimaculata (Table 1). The developmental time from egg to adult of the parasitoid ranged from $34.3 \mathrm{~d}$ at $17^{\circ} \mathrm{C}$ to $8.7 \mathrm{~d}$ at $32^{\circ} \mathrm{C}$. Within the range of $17^{\circ} \mathrm{C}$ to $32^{\circ} \mathrm{C}$, developmental time decreased with increase temperature, however, developmental time was more prolonged when temperature exceeded $32^{\circ} \mathrm{C}$. There were no significant differences between the developmental times, recorded at temperatures ranging from $29^{\circ} \mathrm{C}$ to $32^{\circ} \mathrm{C}$. For temperatures ranging from $17 \sim 35^{\circ} \mathrm{C}$, a total of $181.4 \pm 2.4$ degree-days $(D D)$ were required to complete development with a lower developmental threshold $\left(T_{b}\right)$ at $11.6 \pm 0.3^{\circ} \mathrm{C}$.

Survival from early second instar to adult emergence differed at the 7 temperatures (Table 1). The percentage survival was lowest at $81.3 \%$ at $17^{\circ} \mathrm{C}$, and peaked to $91.0 \%$ at $26^{\circ} \mathrm{C}$. From $17^{\circ} \mathrm{C}$ to $26^{\circ} \mathrm{C}$, survival increased

TABLE 1. Developmental period and percentage survival of immatures of E. bimaculata at seven temperatures.

\begin{tabular}{cccc}
\hline Temperature $\left({ }^{\circ} \mathrm{C}\right)$ & $\mathrm{n}$ & $\begin{array}{c}\text { Developmental period }(\mathrm{d}) \\
\text { Egg to adult, mean } \pm \mathrm{SE}\end{array}$ & $\begin{array}{c}\text { Survival }(\%) \\
\text { Second instar to adult, mean } \pm \mathrm{SE}\end{array}$ \\
\hline 17 & 84 & $34.3 \pm 0.42 \mathrm{a}$ & $81.3 \pm 1.70 \mathrm{~b}$ \\
20 & 86 & $22.8 \pm 0.37 \mathrm{~b}$ & $85.0 \pm 2.17 \mathrm{ab}$ \\
23 & 87 & $15.1 \pm 0.27 \mathrm{c}$ & $85.5 \pm 1.08 \mathrm{ab}$ \\
26 & 92 & $12.1 \pm 0.15 \mathrm{~d}$ & $91.0 \pm 1.84 \mathrm{a}$ \\
29 & 84 & $9.2 \pm 0.22 \mathrm{f}$ & $90.3 \pm 2.55 \mathrm{a}$ \\
32 & 82 & $8.7 \pm 0.58 \mathrm{f}$ & $84.8 \pm 0.97 \mathrm{ab}$ \\
35 & 80 & $10.3 \pm 0.06 \mathrm{e}$ & $83.3 \pm 1.65 \mathrm{~b}$ \\
$\mathrm{~F}$ & & 1375.70 & 14.92 \\
$d f$ & & 6,588 & 6,21 \\
$P$ & & $<0.0001$ & 0.0028 \\
\hline
\end{tabular}

$\mathrm{n}-$ the total number of individuals in 4 replicates. Within the same column the values with different letters are significantly different at $\mathrm{P}<0.05$. 
TABLE 2. Longevity and reproduction of E. bimaculata adults at five temperatures.

\begin{tabular}{|c|c|c|c|c|c|c|}
\hline \multirow{2}{*}{$\begin{array}{c}\text { Temperature } \\
\left({ }^{\circ} \mathrm{C}\right)\end{array}$} & \multirow{2}{*}{$\mathrm{n}$} & \multicolumn{2}{|c|}{ Longevity of female adults (days) } & \multicolumn{3}{|c|}{ Offspring per female } \\
\hline & & Mean \pm SE & Range & Mean \pm SE & Range & Daily reproduction \\
\hline 20 & 84 & $8.4 \pm 0.68 \mathrm{a}$ & $5-10$ & $29.3 \pm 2.91 \mathrm{a}$ & $16-38$ & 3.5 \\
\hline 23 & 84 & $7.6 \pm 0.46 \mathrm{a}$ & $5-9$ & $26.8 \pm 1.88 \mathrm{ab}$ & $17-31$ & 3.5 \\
\hline 26 & 86 & $6.6 \pm 0.42 b$ & $4-8$ & $27.6 \pm 2.11 \mathrm{ab}$ & $15-36$ & 4.2 \\
\hline 29 & 80 & $5.9 \pm 0.27 \mathrm{c}$ & $4-7$ & $26.8 \pm 1.28 \mathrm{ab}$ & $23-33$ & 4.6 \\
\hline 32 & 80 & $5.4 \pm 0.35 \mathrm{c}$ & $4-7$ & $24.3 \pm 2.02 \mathrm{~b}$ & $14-33$ & 4.5 \\
\hline$F$ & & 33.43 & & 130.26 & & \\
\hline$d f$ & & 4,409 & & 4,409 & & \\
\hline$P$ & & $<0.0001$ & & $<0.0001$ & & \\
\hline
\end{tabular}

Within the same column values with different letters are significantly different at $\mathrm{P}<0.05$.

with increasing temperature, however, when the temperature exceeded $29^{\circ} \mathrm{C}$, survival declined markedly. Results indicate that temperatures of $26-29^{\circ} \mathrm{C}$ are optimal for the development of E. bimaculata.

\section{Longevity and reproduction of adults}

Temperature had a significant effect on both the longevity and reproduction of E. bimaculata (Table 2). As expected, longevity decreased as temperature increased with average longevity ranging from $8.4 \mathrm{~d}$ (range 5-10) at $20^{\circ} \mathrm{C}$ to $5.4 \mathrm{~d}$ (range $5-9$ ) at $32^{\circ} \mathrm{C}$. The maximum adult lifespan was $10 \mathrm{~d}$ at $20^{\circ} \mathrm{C}$ decreasing to $4 \mathrm{~d}$ at $26^{\circ} \mathrm{C}, 29^{\circ} \mathrm{C}$ and $32^{\circ} \mathrm{C}$.

The rate of oviposition depended on female age and was strongly related to temperature (Fig. 1). The average number of offspring produced by $E$. bimaculata varied from 29.3 per female at $20^{\circ} \mathrm{C}$ to 24.3 at $32^{\circ} \mathrm{C}$. The maximum number of offspring produced was 38 at $20^{\circ} \mathrm{C}$ and the lowest was 14 at $32^{\circ} \mathrm{C}$. The average daily number of offspring produced per female ranged from 3.5 at $20^{\circ} \mathrm{C}$ to 4.6 at $29^{\circ} \mathrm{C}$. The daily number of offspring produced and the daily survival of females are presented in Fig.1.

\section{Life table parameters}

The effect of temperature on the intrinsic rate of increase $\left(r_{m}\right)$, net reproductive rate $\left(R_{0}\right)$, doubling time $(D T)$, mean generation time $(T)$ and finite rate of increasing $(\lambda)$ are presented in Table 3 . Generation time decreased with increasing temperature, from $29.5 \mathrm{~d}$ at $20^{\circ} \mathrm{C}$ to $11.9 \mathrm{~d}$ at $32^{\circ} \mathrm{C}$. Net reproduction was maximal at $26^{\circ} \mathrm{C}$ (18.2 viable females per female). The doubling time decreased from $7.9 \mathrm{~d}$ to $3.1 \mathrm{~d}$ as temperature increased from $20^{\circ} \mathrm{C}$ to $29^{\circ} \mathrm{C}$. The finite rate of increase peaked at $29^{\circ} \mathrm{C}$ (1.24). The maximum intrinsic rate of increase was $0.2163 \pm 0.01$ at $29^{\circ} \mathrm{C}$, followed by $0.2062 \pm 0.02$ at $32^{\circ} \mathrm{C}$ (viable females per female). The intrinsic rates of increase at the different temperatures differed significantly $(F=$ 1944.42, df $=4,15, P<0.0001)$.

\section{DISCUSSION}

In southern China, surveys have indicated that there are more than 10 species of aphelinids parasitizing B. tabaci, with E. bimaculata being one of the most abundant (Ren et al., 2001; Qiu et al., 2004a). Since 1993, Enkegaard (1993), De Barro et al. (2000), Xu et al. (2003), Antony et al. (2004), Qiu et al. (2004b) have recorded the life history parameters of Encarsia spp. at different temperatures. The use of constant temperatures facilitated the comparison of the performance of these Encarsia parasitoids.

\section{Developmental time}

Developmental times of $E$. bimaculata varied from 9.2 $\mathrm{d}$ to $15.1 \mathrm{~d}$ across the temperature range $23^{\circ} \mathrm{C}$ to $29^{\circ} \mathrm{C}$ when reared on host feeding on eggplants. Over a similar temperature range $\left(22^{\circ} \mathrm{C}\right.$ to $\left.30^{\circ} \mathrm{C}\right)$, the developmental time of E. bimaculata (Bundaberg population) (De Barro et al., 2000) ranged from 16-18 d when reared on host feeding on hibiscus. Antony et al. (2004) report that the developmental periods for male and female E. bimaculata (Indian population), parasitising $B$. tabaci on cassava at $25-30^{\circ} \mathrm{C}$, averaged $12.7 \mathrm{~d}$ and $14.5 \mathrm{~d}$ for females and males, respectively. Within the same genus, $\mathrm{Xu}$ et al. (2003) found that Encarsia formosa require 20.2 d, 14.5 d

TABLE 3. Life table parameters for E. bimaculata at five temperatures $(95 \% \mathrm{CI})$.

\begin{tabular}{cccccc}
\hline $\begin{array}{c}\text { Temperature } \\
\left({ }^{\circ} \mathrm{C}\right)\end{array}$ & $\begin{array}{c}\text { Generation time } \\
(T)(\text { days })\end{array}$ & $\begin{array}{c}\text { Net reproduction } \\
\text { rate }\left(R_{0}\right)\end{array}$ & $\begin{array}{c}\text { Doubling time }(\mathrm{DT}) \\
(\text { days })\end{array}$ & $\begin{array}{c}\text { Finite rate of } \\
\text { increase }(\lambda)\end{array}$ & $\begin{array}{c}\text { Intrinsic rate } \\
\text { of increase }\left(r_{m}\right) *\end{array}$ \\
\hline 20 & 29.50 & 11.09 & 7.87 & 1.09 & $0.0816 \pm 0.013 \mathrm{e}$ \\
23 & 22.04 & 16.31 & 5.28 & 1.14 & $0.1267 \pm 0.009 \mathrm{~d}$ \\
26 & 15.30 & 18.21 & 3.52 & 1.21 & $0.1892 \pm 0.016 \mathrm{c}$ \\
29 & 11.92 & 13.15 & 3.13 & 1.24 & $0.2163 \pm 0.010 \mathrm{a}$ \\
32 & 12.85 & 14.16 & 3.19 & 1.23 & $0.2062 \pm 0.022 \mathrm{~b}$ \\
\hline
\end{tabular}

* Within the column of $r_{m}$, the values with different letters are significantly different at $\mathrm{P}<0.05(F=1944.42, d f=4,15, P<$ $0.0001)$. 
A $20^{\circ} \mathrm{C}$

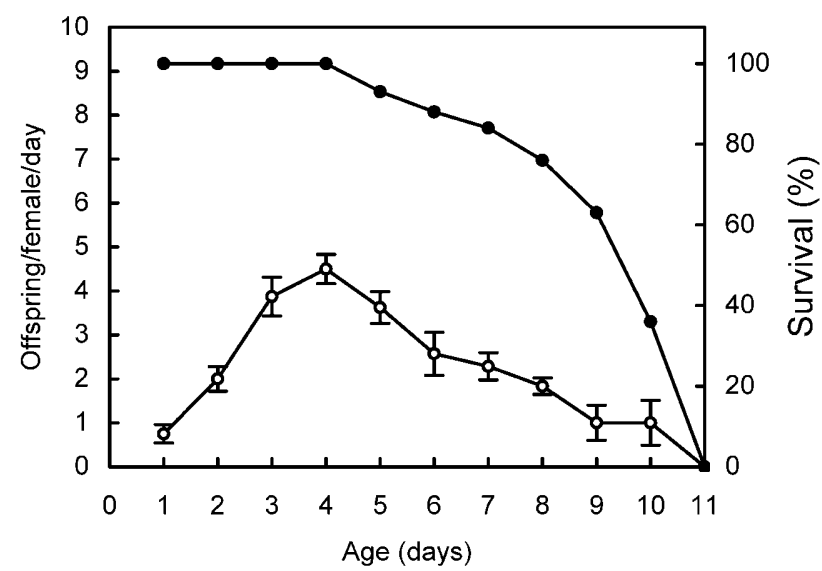

B $23^{\circ} \mathrm{C}$

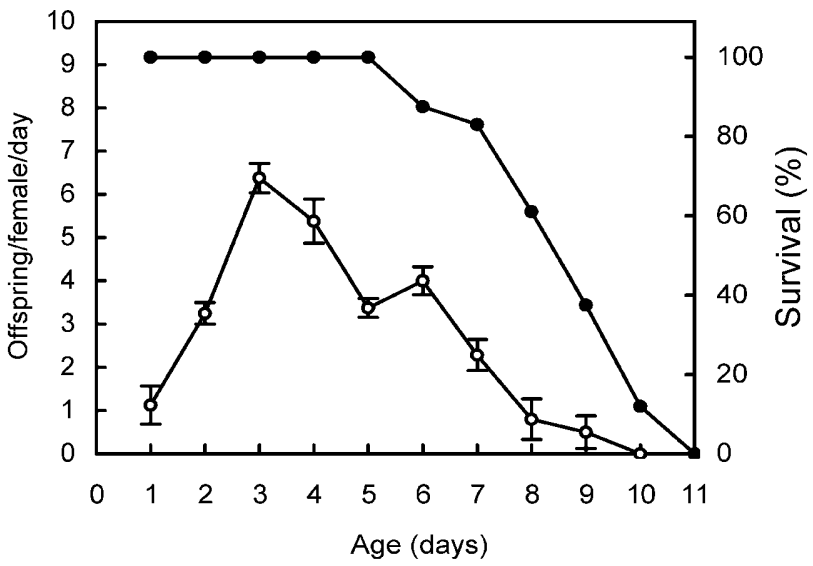

C $26^{\circ} \mathrm{C}$

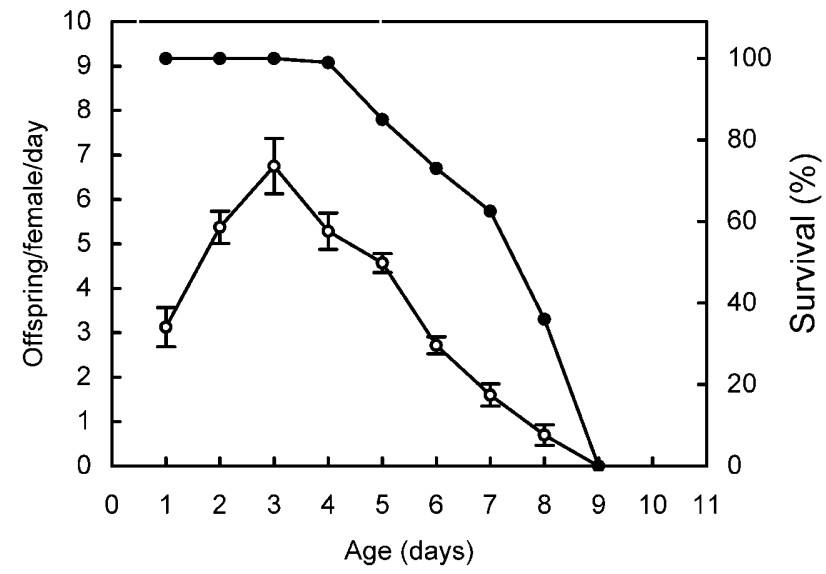

and $12.9 \mathrm{~d}$ for development at $20^{\circ} \mathrm{C}, 25^{\circ} \mathrm{C}$ and $30^{\circ} \mathrm{C}$, respectively, while Qiu et al. (2004b) report that the development period of $E$. formosa at $32^{\circ} \mathrm{C}$ is about $14 \mathrm{~d}$. While temperature clearly influences the rate of development, the above differences are also likely to be affected by differences in the genetic stock from which the parasitoids were obtained and the host plant of the whitefly host.

\section{D $29^{\circ} \mathrm{C}$}

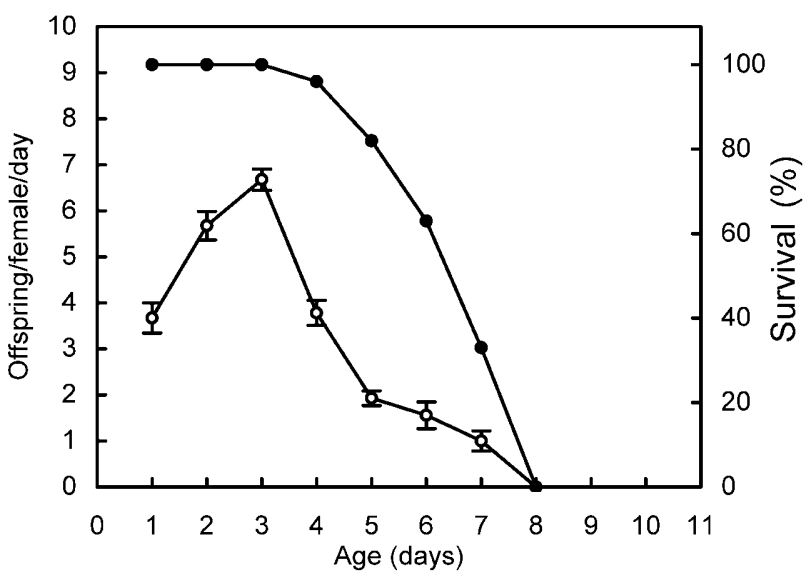

E $32^{\circ} \mathrm{C}$

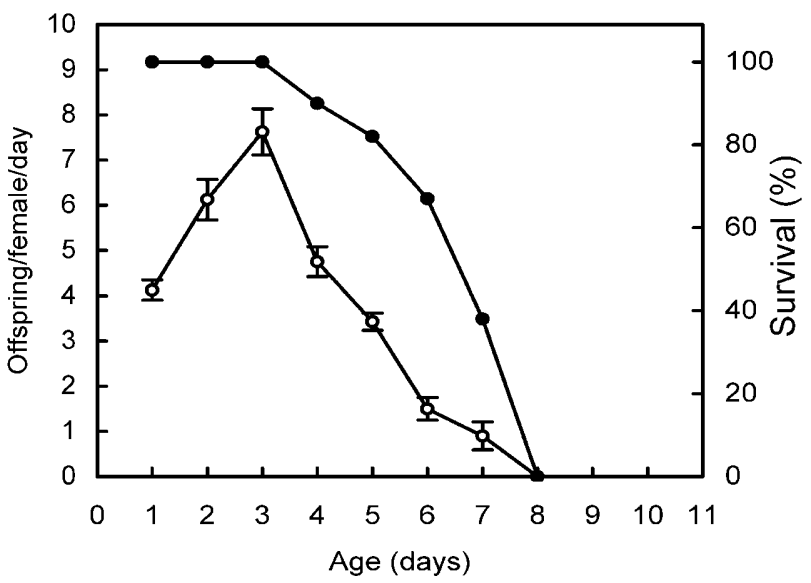

Fig. 1. Oviposition (circles) and observed age-specific survival (solid dots) of E. bimaculata at 20, 2326,29 and $32^{\circ} \mathrm{C}$ (A-E) on eggplant.

\section{Longevity of adult}

The longevity of E. bimaculata at different temperatures has not been previously reported. However, there are several such studies on $E$. formosa parasitising $B$. tabaci (Bethke et al., 1991; Enkegaard, 1993; Xu et al., 2003). In these studies, the adult longevity of $E$. formosa is reported to be $4.8 \mathrm{~d}$ at $25.4^{\circ} \mathrm{C}$ (Bethke et al., 1991), $15.2 \mathrm{~d}$ at $22^{\circ} \mathrm{C}, 9.2 \mathrm{~d}$ at $28^{\circ} \mathrm{C}$ (Enkegaard, 1993), $17.7 \mathrm{~d}$ at $25^{\circ} \mathrm{C}$ and $13.6 \mathrm{~d}$ at $30^{\circ} \mathrm{C}$ (Xu et al., 2003). In the present study, the longevity of E. bimaculata was $7.6 \mathrm{~d}$ at $23^{\circ} \mathrm{C}$ 


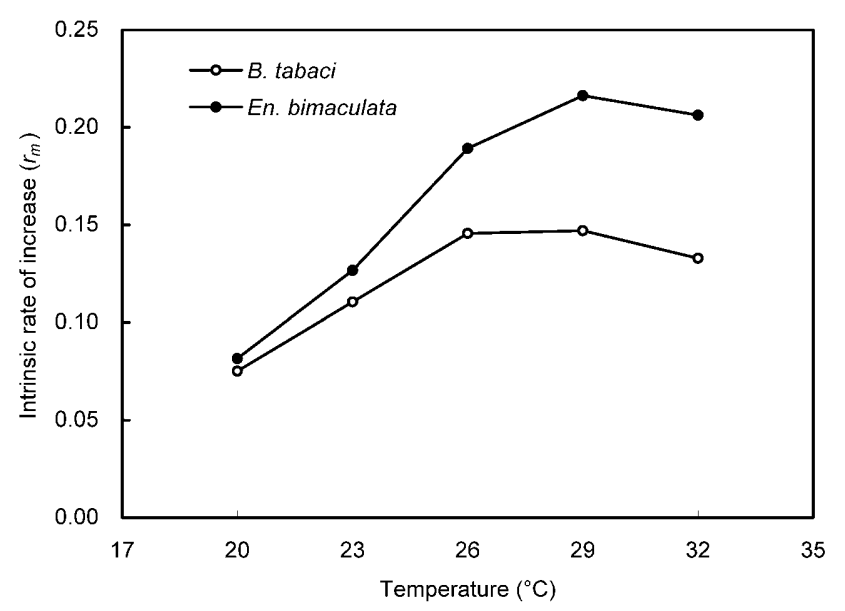

Fig. 2. Intrinsic rate of increase $\left(r_{m}\right)$ of E. bimaculata (solid dots) and B. tabaci B biotype (circles) on eggplant at five constant temperatures. The data for $B$. tabaci is taken from Qiu et al. (2003).

and $5.9 \mathrm{~d}$ at $29^{\circ} \mathrm{C}$, which is shorter than that reported for E. formosa.

\section{Reproduction}

De Barro et al. (2000) studied the mean daily and total number of ovipositions made by $E$. bimaculata over a 10 -day period on five host plants at $22-30^{\circ} \mathrm{C}$. The mean daily oviposition ranged from 1.7 on soybean to 3.9 on hibiscus with an average of 2.9, whereas the average daily parasitization in our study on eggplant ranged from 3.5 at $20^{\circ} \mathrm{C}$ to 4.6 at $29^{\circ} \mathrm{C}$. Records of E. bimaculata on rockmelon and hibiscus at $22-30^{\circ} \mathrm{C}$ (De Barro et al., 2000) were closer to the rate observed in our study over the same temperature range. The oviposition of $E$. bimaculata peaked on day 3 when parasitizing $B$. tabaci on rockmelon, cotton, tomato, soybean and hibiscus (De Barro et al., 2000), which is as the result reported here at 23, 26, 29 and $32^{\circ} \mathrm{C}$. In De Barro et al. (2000) the total number of nymphs parasitized was 11.3 nymphs on soybean, 16.3 on tomato, 26.0 on rockmelon, and 27.8 and 29.5 on hibiscus and cotton, respectively. In our study, the total number ranged from 24.3 nymphs at $32^{\circ} \mathrm{C}$ to 29.3 at $20^{\circ} \mathrm{C}$, which is higher than that reported on soybean and tomato, but similar to rockmelon, hibiscus and cotton. In contrast $\mathrm{Xu}$ et al. (2003) observed fecundities for E. formosa of 136.7, 132.0 and 124.0 eggs at 20, 25 and $30^{\circ} \mathrm{C}$, respectively, which are much higher than those for E. bimaculata reported by both our and De Barro et al. (2000).

\section{Comparison of life table parameters of parasitoid and host}

The $r_{\mathrm{m}}$ values for E. bimaculata at five constant temperatures ranged from 0.0893 at $20^{\circ} \mathrm{C}$ to 0.2421 at $29^{\circ} \mathrm{C}$, while that of $B$. tabaci $\mathrm{B}$ biotype at the same temperatures varied from 0.0751 at $20^{\circ} \mathrm{C}$ to 0.1470 at $29^{\circ} \mathrm{C}$ (Fig. 2) (Qiu et al., 2003b). This along with the values for $R_{o}, T$ and $\lambda$ indicate that E. bimaculata is better adapted to high temperatures than B. tabaci. This suggests that within the range of $20-32^{\circ} \mathrm{C}$, and especially at $26-32^{\circ} \mathrm{C}$, E. bimaculata could intrinsically control B. tabaci $\mathrm{B}$ biotype.

ACKNOWLEDGEMENT. The authors thank J. Huang (Fujian Agricultural and Forestry University, China) for his assistance in identifying the species of Encarsia bimaculata, and L. Lin (Department of Entomology, SCAU, China) for her technical assistance. This research was funded by the China National Natural Science Foundation (30400292), National Basic Research Program of China (973-2006 CB102005) and Natural Science Foundation of Guangdong Province of China (04020604).

\section{REFERENCES}

Antony B., Palaniswami M.S., Kirk A.A. \& Henneberry J.T. 2004: Development of Encarsia bimaculata (Heraty \& Polaszek) (Hymenoptera: Aphelinidae) in Bemisia tabaci (Gennadius) (Homoptera: Aleyrodidae) nymphs. Biol. Contr. 30: $546-555$.

Bethke J.A., Nuessly G.S., Paine T.D. \& Redak R.A. 1991: Effect of host insect-host plant association on selected fitness components of Encarsia formosa (Gahan) (Hymenoptera: Aphelinidae). Biol. Contr. 1: 164-169.

BIRCH L.C. 1948: The intrinsic rate of natural increase in an insect population. J. Anim. Ecol. 17: 15-26.

Brown J.K., Frohlich D.R. \& Rosell R.C. 1995: The sweetpotato or silverleaf whiteflies: Biotypes of Bemisia tabaci or a new species complex. Annu. Rev. Entomol. 40: 511-534.

Byrne F.J., Castle S., Prabhaker N. \& Toscano N.C. 2003: Biochemical study of resistance to imidalcoprid in B biotype Bemisia tabaci from Guatemala. Pest Manag. Sci. 59: 347-352.

Chou I. 1949: List of whitefly species in China. J. Chin. Entomol. 3: 1-18.

Costa H.S., Brown J.K., Sivasupramaniam S. \& Bird J. 1993: Regional distribution, insecticide resistance, and reciprocal crosses between the ' $A$ ' and ' $B$ ' biotypes of Bemisia tabaci. Insectic. Sci. Appl. 14: 127-138.

De BARRo P.J. \& Driver F. 1997: Use of RAPD PCR to distinguish the B biotype from other biotypes of Bemisia tabaci (Gennadius) (Homoptera: Aleyrodidae). Austr. J. Entomol. 36: $149-152$.

De Barro P.J., Hart P.J. \& Morton R. 2000: The biology of two Eretmocerus spp. (Haldeman) and three Encarsia spp. Forster and their potential as biological agents of Bemisia tabaci B biotype in Australia. Entomol. Exp. Appl. 94: 93-102.

De Barro P.J., Trueman J.W.H. \& Frohlich D.R. 2005: Bemisia argentifolii is a race of B. tabaci (Hemiptera: Aleyrodidae): the molecular genetic differentiation of B. tabaci populations around the world. Bull. Entomol. Res. 95: 193-203

ENKEGAARD A. 1993: Encarsia formosa parasitizing the poinsettia-stain of the cotton whitefly, Bemisia tabaci on poinsettia: bionomics in relation to temperature. Entomol. Exp. Appl. 69: 251-261.

Frohlich D.R., Torres-Jerez I., Bedford I.D., Markham P.G. \& Brown J.K. 1999: A phylogeographical analysis of the Bemisia tabaci species complex based on mitochondrial DNA markers. Mol. Ecol. 8: 1683-1691.

Gerling D., Alomar S. \& Arno J. 2001: Biological control of Bemisia tabaci using predators and parasitoids. Crop Prot. 20: 779-799.

Liu T.-X. \& Stansly P.A. 1996: Oviposition, development, and survivorship of Encarsia pergandiella (Hymenoptera: Aphe- 
linidae) in four instars of Bemisia argentifolii (Homoptera: Aleyrodidae). Ann. Entomol. Soc. Am. 89: 96-102.

Luo C., Yao Y., Wang R.J., Yan F.M., Hu D.X. \& Zhang Z.L. 2002: The use of mitochondrial cytochrome oxidase I (mtCOI) gene sequences for the identification of biotypes of Bemisia tabaci (Gennadius) in China. Acta Entomol. Sin. 45: 759-763.

Maia A. De H.Z., Luiz A.J.B. \& Campanhola C. 2000: Statistical inference on associated fertility life table parameters using jackknife technique: Computational aspects. J. Econ. Entomol. 93: 511-518.

McAuslane H.J. \& Nguyen R. 1996: Reproductive biology and behavior of thelytokous species of Eretmocerus (Hymenoptera: Aphelinidae) parasitizing Bemisia argentifolii (Homoptera: Aleyrodidae). Ann. Entomol. Soc. Am. 89: 686-693.

Qiu B.-L. \& REN S.X. 2005: Effect of host plants on the development, survivorship and reproduction of Encarsia bimaculata (Hymenoptera: Aphelinidae), a parasitoid of Bemisia tabaci (Homoptera: Aleyrodidae). Acta Entomol. Sin. 48: 365-369.

Qiu B.-L., Ren S.X., Wen S.Y. \& Mandour N.S. 2003a: Biotype identification of the populations of Bemisia tabaci (Homoptera: Aleyrodidae) in China using RAPD-PCR. Acta Entomol. Sin. 46: 605-608.

Qiu B.-L., Ren S.X., Mandour N.S. \& Lin L. 2003b: Effects of temperature on the development and reproduction of Bemisia tabaci B biotype (Homoptera: Aleyrodidae). Entomol. Sin. 10: $43-49$.
Qiu B.-L., Ren S.X., Lin L. \& Wang X.M. 2004a: Species and dynamics of aphelinid parasitoids of Bemisia tabaci in Guangdong area. Entomol. Knowl. 41: 18-22.

Qiu Y.T., van Lenteren J.C., Drost Y.C. \& PosthumaDoodeman C.J.A. 2004b: Life-history parameters of Encarsia formosa, Eretmocerus eremicus and E. munds, aphelinid parasitoids of Bemisia argentifolli (Hemiptera: Aleyrodidae). Eur. J. Entomol. 101: 83-94.

Qiu B.-L., De Barro P.J. \& Ren S.X. 2005: Development, survivorship and reproduction of Eretmocerus sp. nr. furuhashii (Hymenoptera: Aphelinidae) parasitizing Bemisia tabaci (Hemiptera: Aleyrodidae) on glabrous and nonglabrous host plants. Bull. Entomol. Res. 95: 313-319.

Ren S.X., Wang Z.Z., Qiu B.-L. \& XiaO Y. 2001: The pest status of Bemisia tabaci in China and non-chemical control strategies. Entomol. Sin. 18: 279-288.

SAS Institute 2003: SAS/STAT Version 8.2. SAS Institute, Cary, NC.

WANG K. \& TSAI J.H. 1996: Temperature effect on development and reproduction of silverleaf whitefly (Homoptera: Aleyrodidae). Ann. Entomol. Soc. Am. 89: 375-384.

Wu X.X., Li Z.X., Hu D.X. \& SHEN Z.R. 2003: Identification of Chinese populations of Bemisia tabaci (Gennadius) by analyzing ITS1 sequence. Progr. Nat. Sci. 13: 276-281.

Xu W.H., Zhu G.R., Li G.L., Xu B.Y., Zhang Y.J. \& Wu Q.J. 2003: Influence of temperature on the biology of Encarsia formosa parasitizing the whitefly Bemisia tabaci. Chin. J. Biol. Contr. 19: 103-106.

Received March 3, 2006; revised and accepted July 30, 2006 